\title{
Comparative Morphological Studies on the Quadra- tomandibular Articulation in Hooded Crow (Corvus cornix) and Cattle Egret (Bubulcus ibis)
}

\section{S. A. Hassan}

Dept. of Anatomy and Embryology, Fac. Vet. Med, Suez Canal Univ., EGYPT

\section{Abstract}

The morphology of the quadratomandibular joint was investigated in Hooded crow (omnivorous bird) and Cattle egret (carnivourous bird). We investigated the articular surfaces and the capsule. The quadrato-mandibular joint in both birds was formed by the quadrate bone of the skull and the articular bone of the mandible. The articulation lacked the fibrocarilagenous disks which commonly present in the tempro-mandibular joint in mammalian species. The differences between the two birds were in the size of the articular surface, thickness of the fibrous layer of the joint capsule and the site of attachments of the ligaments. These differences might be correlated with the different patterns of feeding behavior. We also suggested the suitable site for the intraarticular injection of this joint in both bird species which might help in the treatment of the joint affections.

\section{Key Words}

Quadratomandibular joint, Hooded crow, Cattle rgret.

\section{Introduction}

Much interest in avian structures and their functions has increased with the increasing importance of birds as food producers, as models in biological research, and as pets (McLelland, 1990).

Some studies have been done on the morphology of the quadratomandibular joint in different birds (Fujioka, 1963; Baumel, 1975 ; King and McLelland, 1975; Nickle et al., 1977; King and McLelland, 1984; Selianski,1986; McLelland, 1990 and Dyce et al., 2002) but detailed information about the morphology of the joint is insufficient especially in Hooded crow and Cattle egret which have different feeding habits. Pathological conditions of the joints of the skull such as myco- 
plasmosis, infectious coryza and staph. aureus infections are frequently occurring problems in birds especially in pheasants. These conditions could be treated with local injection of such joints with proper pharmacological agents (Joine and More, 2003) Knowledge of the anatomical features of skull joints is imperative for proper treatment of their pathological conditions.

The Hooded Crow (Corvus cornix) is an omnivorous bird and is a constant scavenger (Cocker et al., 2005). The Hooded Crow is an opportunistic predator and scavenger using mostly visual cues to find a wide range of food including grain, small mammals, carrion and rubbish (Coombs, 1978; Yom-Tov, 1974). It is a major predator of bird's eggs and young (Mehlum, 1991; Luginbuhl et al., 2001and Sullivan and Dinsmore, 1990).

The Cattle Egret (Bubuleus ibis) feeds on a wide range of prey, particularly insects (Seedikkoy et al. 2007), moths, spiders, and frogs, as well as earthworms (Siegfried, 1971 and Fogarty et al., 1973). In a rare instance they have been observed foraging along the branches of a Banyan tree (Chaturvedi, 1993). The role of this bird in management of insect pests in different agro-ecosystems is also reported by Yadav (2000) and Middlemiss (1955). In South Africa they have much importance as con- troller of dipterous pests of Cattle (Blaker 1969). Ali (2002) and Siegfred (1972) have recorded the presence of pray items as green blowfly of the family califorida in the food of this bird.

The study was carried out to obtain some information about the gross anatomical features of the quadratomandibular joint in Hooded crow as an omnivourus bird and Cattle egret as a carnivourous bird. Such information is useful in understanding the different mechanisms of feeding and drinking habits and in determining the proper site for itra-articular injection of the joint.

\section{Materials and Methods}

The current work was carried out on eight heads of freshly slaughtered healthy adult birds of each species (Hooded crow and Cattle egret) that were collected from the wild bird hunters in Damietta governorate, Egypt.

Species identification and age determination were adopted according to Klos and Lang (1982).

Four specimens of each species were used for the description of the gross anatomical features of the joint. Three specimens were used to describe the anatomical features of the articular surfaces. 
The anatomical morphometery was carried out using Varnier's caliber. The remaining specimen was used for locating the exact site of intra-articular injection.

The anatomical terms were adopted according to the Nomina Anatomica Avium (1979).

\section{Results}

The current study revealed that the quadrato-mandibular joint in Hooded crow and Cattle egret was positioned nearly at the same level of the dorsal border of the ramus of the mandible. The joint is formed by the quadrate bone and the articular bone of the mandible. The articular surfaces of the joint included the articular surface of the articular bone (Fossa articularis quadratic) and the mandibular process of the quadrate bone ( figs. 1, 2, $3 \& 4)$.

\section{A) Articular surfaces}

The articular surfaces of the bony elements of the quadratomandibular joint in both Hooded crow and Cattle egret were congruent and articulate with each other only by their articular cartilages without intervening disc.

\section{I-Hooded crow}

The quadrate bone of the Hooded crow is irregular quadrangular with rounded angles (fig. 3). Quadratum was the link between the mandible and cranium. It possess the otic, orbital and mandibular processes. The otic process (Processus oticus quadrati) articulates with the faces articularis quadratica of Os temporale rostral to the external acoustic meatus. The orbital process (Processus orbitalis quadrati) is long cylindrical with elongated free end which directed toward the orbit for muscular attachment. The shortest strongest process is the mandibular process (Processus mendibularis quadrati) which articulates with the mandible.

The mandibular process carries ventrally three articular condyles (lateral, medial and caudal) (fig. $1 \mathrm{a} \& \mathrm{~b}$ ). The lateral condyle carries a cotyla on its lateral side for articulation with the caudomedial surface of the Os quadrate- jugal. The articular surface of the condyle is elongated convex about $0.45 \mathrm{~cm}$ long and $0.35 \mathrm{~cm}$ wide.

The medial condyle (fig. 1a) is longer but narrower than the lateral one. It is strongly convex, oval in shape (about $0.48 \mathrm{~cm}$. long and $0.24 \mathrm{~cm}$ wide. this condyle was attached medially with the process quadraticum of the ptregoid bone.

These condyles articulate ventrally with the cotyla of the articular bone of the mandible. The two condyles were separated rostrally by sagittal synovial fossa and caudally by small intercondylar tubercle which articulates with a 
small facet present just caudal to the lateral cotyla of the mandible.

The quadrate has an articular fossa (fig. 1a) which articulates with the condyles of the articular bone of the mandible. This articular fossa is composed of two cotylae (medial and lateral) which act as a socket for the condyles of the articular bone of the mandible. These cotylae were strongly interlocked with the condyles of the mandible.

The smaller lateral cotyla (fig. 1b) is slightly concave and articulates with the corresponding articular area of the lateral condyle of the quadrate. Just caudal to the lateral cotyla there is a small elongated articular facet which articulates with the articular tubercle of the mandibular process of the quadrate bone.

The medial cotyla (fig. 1b) is larger and deeper than the lateral one and articulates with the medial condyle of the quadrate bone. It is bounded medially by the medial mandibular process. There is a small tubercle intercotylae found rostrally between the two cotylae. This tubercle lodged in a small depression found between the lateral and medial condyles of the quadrate bone when the jaws are closed.

\section{II-Cattle egret}

There were few differences between the articular surfaces of the bony ele- ments of the joint in the Cattle egret and Hooded crow

Quadrate bone (fig. 4) was molar tooth-like and smaller than that of the Hooded crow. The mandibular process of the quadrate bone had 3 articular condyles that articulate with the articular bone of the mandible. The 3 condyles are nearly equal in size. The medial condyle is attached with the ptregoid bone, the lateral condyle articulates laterally with the caudal extremity of the quadrate-jugal bone which might stabilize the joint. The $3^{\text {rd }}$ condyle is located caudally. The lateral, medial and caudal condyles of the quadrate bone articulate with three small articular fossae (lateral medial and caudal respectively) (fig. 2) which were found in the dorsal surface of the articular bone of the mandible. The medial facet is the largest while the caudal one is the smallest.

Like Hooded crow, the quadratomandibular joint in Cattle egret free from intra-articular disks or menisci.

\section{B) Articular capsule}

\section{I-Hooded craw}

The fibrous capsule (fig. 5) was tight attached to the margin of the articular surfaces. It extended dorsally to end at the postorbital process of the temporal bone. The fibrous capsule extended rostrally covering the caudal one third of the quadratojugal bone and extended caudally till the zygomatic process of the temporal bone. 
Ventrally, the fibrous capsule is attached about $0.2 \mathrm{~cm}$ from the articular margin of the articular bone of the mandible. The capsule was reinforced with long narrow fibrous band (Lig. Jugomandibularis lateralis ) (fig. 7/2) attached dorsally to the lateral surface of the lateral condyle of the quadrate bone and lateral surface of the caudal end of the quadratojugal bone extended rostroventrally to be ended in the upper part of the lateral aspect of the articular bone of the mandible. The jugomandibular ligament measured about $0.6 \mathrm{~cm}$ long and about 0.1 $\mathrm{cm}$ wide.

The $2^{\text {nd }}$ ligament (Lig. Jugomandibularis medialis) (fig. 7/3) is a thicker fibrous band extends from the ventral aspect of the caudal end of the quadratojugal bone and directed caudoventrally, passing around the lateral and caudal margin of the articular surface to be inserted in the caudal edge of the articular bone of the mandible just medial to the articular facet of the lateral cotyla.

The cylindrical occipitomandibular ligament (fig. 9/1) is found between the ventral end of the paroccipital process of the occipital bone and the caudal edge of the articular bone of the mandible.

There is a long condensed fibrous band (Lig. postorbitale) fig. (7/1) which begins in the zygomatic process of the temporal bone (this process is fused with the postorbital process) then directed rostroventrally crossing the lateral aspect of the caudal one third of the quadratojugal bone to end just rostral to the insertion of the quadratojugomandibular ligament in the upper part of the lateral surface of the articular bone of the mandible but, about $0.2 \mathrm{~cm}$ from the articular margin of the joint.

The synovial layer of the capsule was thin and limited only on the articular margin of the joint

\section{II-Cattle egret}

The fibrous capsule in the Cattle egret is thinner than that of Hooded crow attached with the margin of the articular surface fig. (6). It is difficult in gross dissection to separate it from the synovial layer.

The fibrous capsule is reinforced by three ligamentus bands. The first is the lig. postorbital (fig. 8) which begins in the zygomatic process of the temporal bone (this process is separated from the postorbiatal process), runs distally crossing the lateral aspect of the caudal end of the quadratojugal bone then deeps under the quadratomandibular ligament to end in the lateral margin of the articular bone of the mandible just rostral to the articular surface

The $2^{\text {nd }}$ ligament is the lateral jugomandibular ligament (fig. 8/2) which is thick short fibrous band originated 
from the lateral aspect of the caudal end of the quadratojugal bone then passes rostroventrally crossing the joint to end in the dorsal border of the lateral aspect of the articular bone of the mandible, about $0.1 \mathrm{~cm}$ from the joint.

The third ligament is the medial quadratomandibular ligament (fig. 8/3) which is long narrow fibrous band begins in the lateral aspect of the lateral condyle of the quadrate bone, courses caudally on the lateral aspect of the ventral margin of the quadrate bone to end in the caudal margin of the lateral cotyla of the articular bone of the mandible.

The occibitomandibular ligament (fig. 10 ) is narrow short fibrous band found between the ventral end of the paroccipital process of the occipital bone and the caudal edge of the articular bone of the mandible.

\section{C) Site of Injection}

The suitable site of injection in the cavity of the joint in the Hooded crow is just above the caudal end of the articular bone of the mandible which can be palpated on the live bird, the needle is inserted horizontally to enter the joint (fig. 11).

In the Cattle egret, the best site of injecting the joint is $1 \mathrm{~mm}$ below the imaginary line between the caudal end of the joint and the mouth commissar $0.3 \mathrm{~cm}$ rostral to the caudal end of the joint. Insertion of the needle horizontally about $0.1 \mathrm{~cm}$ to enter the joint cavity (fig. 12).

\section{Discussion}

The bones forming the quadratomandibular joint in both Hooded crow and Cattle egret were similar to that found in other domestic and wild birds as stated by King and McLelland (1975); Vandenberg (1975); Nickel et al (1977); MacLelland (1990); Kent and Car (2001) and Dyce et al (2002). The previous authors mentioned that the quadratomandibular joint in birds was formed by the quadrate bone of the skull and the articular bone of the mandible. The findings of this study did not observe any fibrocartilagenous disks in the joint in Hooded crow or Cattle egret. These results were in a line with that recorded by Nickle et al (1977) and King \& MacLelland (1984) in domestic birds. However Hofer (1945) and Zweers (1974) reported a wedge-shaped meniscus in the caudal part of the quadratomandibular joint in Anas, Aser and Carina.

The current study named the joint by the bone entered in its formation (quadrate and mandible) according to NAA. On the other hand, Zusi (1967) stated that this joint in birds can be named quadratoarticularis. 
The absence of intervening intra-articular fibrocartolagenous discs may be due to the congruence of the articular surfaces of the quadrate bone and the articular bone of the mandible. However in domestic animals the articular surfaces of the joint are incongruent so the joint need an intervening intraarticular disc in the tempromandibular joint as described in equine and canine by Baumel (1975), rumenants by Erasha et. Al. (1992) and camel by Erasha (2000).

The articular bone of the mandible in mammals form the auditory ossicles (malleus and incus respectively) as mentioned by King and MacLeland (1984)

Unlike fowl, the zygomatic process of the temporal bone in Cattle egret are not fused while in the Hooded crow this finding was on line with that found in fowl by Nickle et al. (1977), .The three processes of the quadrate bone in Hooded crow and Cattle egret were also recorded in fowl, duck, gees and pigeon (Feducia, 1975; shaisson, 1984, King and McLelland, 1984 and Selenski, 1986 and Shevily, 1987. The orbital process of the quadrate bone is elongated like that reported in pigeon by Shaisson (1984).

Unlike ostrich (Imam and Elmahdy 2004) the mandibular process of the quadrate bone in both crow and Cattle egret carries three condyles. On other hand, these results were on line with that reported by Imam and Elmahdy (2004) in flamingo and Bock (1960) in most birds.

The obtained results declared that the primary role of the quadrate bone is to connect the skull to the mandible. This is in agreement with Feducia (1975) in domestic birds and added that it is the basis of cranial kinesis. The articulation between the quadrate and the caudal part of the quadratojugal bone observed in this study, it is also reported by Nickle et. al.(1977), Baumel (1979) and King and McLelland (1984) in other birds. The jugal arch is homologue to the zygomatic arch in mammals (Dyce at al. 2002).

Regarding the articular surfaces of the articular bone of the mandible it consists of two cotylae in the Hooded crow which receive the codyles of the mandibular process of the quadrate bone. In Cattle egret it consists of three small grooves rather than cotylae like that mentioned by Baumed (1979) in domestic birds.

the two articular surfaces of both quadrate and mandible are tightly interlocked in both crow and Cattle egret, whereas in other birds like $R y$ chops nigr they have a weak interlock.

The medial process of the mandible articulates with the lateral or medial basitemporal process to support the mandible and prevent dislocation of the joint (Bock, 1960), however, zusi 
(1976) disagreed with the idea of the before mentioned author.

Unlike Imam and Elmahdy (2004) in ostrich and Bock and Morony (1972) in most passerines, the lig. Quadratomandibularae was not detected in the species studied,

This study recorded the lig. Occipitomandibulae in both Hooded crow and Cattle egret which is on line with Imam and Elmahdy (2004) in ostrich and Bock (1960) in crovus. Imam and Elmahdy (2004) did not record this ligament in flamingo.

\section{References}

Ali (2002): The book of Indian birds. $13^{\text {th }}$ ed. Bombay Natural History Society \&Oxford University Press, $326 \mathrm{pp}$.

Baumel, J.J. (1975): Aves skeletal system. In Sisson and Grossman's; The Anatomy of the Domestic Animals, $5^{\text {th }}$ ed. .R. Getty, Vol. 2, pp. 2044-2052. W.B. Saunders Company, Philadelphia, London \& Toronto

Baumel, J.J. (1979): Systema cardiovasculare. In Nomina Anatomica Avium. ed. by Baumel, J.J.; King, A.S.; Lucas, A.M.; Breazile, J.E. and Evans, H.E., London, New York, Academic Press.

Blakar B R (1969): Behavior of the
Cattle egret. Ostrich 40 (3): 75-129

Bock, W. J. (1960): Kinesis of the avian skull J. Morph. 114: 142.

Bock, W. J. and Morony, J. (1972):

Snap-closing jaw ligaments in flycatchers. Amer. Zool., 12: 729-730.

Chaturvedi, N. (1993): Dietary of the Cattle egret Bubulcus ibis coromandus (Boddaert). Journal of the Bombay Natural History Society 90 (1): 90.

Chiasson, R. B. (1984): Laboratory anatomy of the pigeon. $3^{\text {rd }}$ ed., Pp. 7-11, 24-26, wm. C. Brown Publishers, Dubuque, lowa.,

Cocker, Mark; Mabey, Richard (2005)

:Birds Britannica. London: Chatto \& Windus. pp. 418 425. ISBN 0-7011-6907-9.

Coombs, F. (1978): The crows: a study of the corvids of Europe, Batsford.

Dyce, K.M.; Sack, W.O. and Wensing, C.J.G. (2002) :Textbook of Veterinary Anatomy. 3rd ed. pp. 802, 803. Saunders, Philadelphia, London, New York, St. Louis, Sydney, Toronto.

Erasha A. M. (2000): " Some anatomical studies on the temromandibular joint of the onehumped camel (Camelus dromedarius). Assiut Vet. Med. J., 43 (86): Pp. 1-14. 
Erasha, A. M., Ragab, G. A., Ahmed, A. S. (1992): Anatomical and radiological observation on the tempromandibular articulation in various animals, part I: Ruminants. Vt. Med. J. Giza, 40 (3), Pp. 9-16.

Feduccia, A. (1975): Aves Osteolo gy." In Sisson and Grossman's. The Anatomy of the Domestic Animals, 5th ed. R. Getty, Vol. 2, Pp. 1790-1793. W.B. Saunders Company, Philadelphia, London \& Toronto.

Fogarty, Michael J.; Hetrick, Willa Mae (1973): Summer Foods of Cattle Egrets in North Central Florida. The Auk 90 (2): 268280.

Fujioka,T. (1963): comparative and topographic anatomy of the fowl part I. Muscles of the head. " Jap. J. Vet. Sci., 25, Pp. 207-226.

Hofer, H. (1945): Untersuchengen über den Bau des Vogelschädels, basonders über den der Spechte und Steisshühner. Zool. Jb. (Abt Anat. V. Ontogenie d. Tiere): 69. Pp. 1158.

Imam, H. M. and Elmahdy, O. M. (2004): Some anatomical studies on the quadratomandibular articulation of ostrich (Struthio camelus) and Flamingo ( Phoenicopterus ruber). Assiut
Vet. Med. J. 50 (102): Pp., 120.

Joine, B. and More, M. (2003):

Some studies on the joint affections in the True Silver Pheasant J. Wild Life, 130(2), 150-153.

Kent, G.C. and Carr, R.K.(2001):

Comparative Anatomy of

Vertebrates. 9th ed., pp. 179-182.

King, A.S. and McLelland, J. (1975):

Outlines of Avian Anatomy .1st ed. Bailliere, Tindall, London.

King, A.S. and McLelland, J. (1984): Birds, their structure and function. 2nd ed., Pp. 43-51, Bailliere, Tindall, London, Philadelphia, Toronto, Mexico, Rio de Janeiro, Sydney, Tokyo, Hong Kong.

Luginbuhl, J. M., Marzluff, J. M., Bradley, J. E., Rabhael, M. G. and Varland, D. E. (2001): Corvid survey techniques and the relationship between corvid relative abundance and nest predation. -Journal of Field Ornithology, 72: 556572.

Mehlum, F. (1991): Egg predation in a breeding colony of the Common Eider Somateria mollissima in Kongsfjorden, Svalbard. -Skrifter- Norsk Polarinstitutt: 37-45.

McLelland,J.(1990):A colored atlas 
of avian anatomy ,Wolfe publishing LTD, London, England.

Middlemiss E H J (1955): Food of egrets. Ostrich 26: 159

Nickel,R.;Schummer,A. and Seiferle, E. (1977): Anatomy of the Domestic Birds, chapter (blood and vascular system), Verlag Paul Parey, Berlin and Hamburg. Pp (96-99)

Seedikkoya K, PA Azeez, EA Abdul Shukkur (2207): Cattle egret as a biocontrol agent (PDF). Zoos' Print Journal 22 (10): 2864-2866.

Selianski, V. M. (1986): Anatomy and Physiology of Domestic Birds" Klos;

Siegfried, W. R. (1971): The Food of the Cattle Egret. Journal of Applied Ecology (British Ecological Society) 8 (2): 447468. doi:10.2307/2402882. JSTOR 2402882.

Siegfried W R (1972): Aspects of feeding ecology of Cattle egret in south Africa. Journal animal ecology 41 (71-78).

shevily, M. J. (1987): Veterinary

Anatomy. Basic, Comparative and Clinical." $2^{\text {nd }}$ ed., Pp. 469489.

Sullivan, B. D. and Dinsmore, J. J.
(1990): Factors affecting egg predation by American crows. -Journal of Wildlife Management, 54: 433-437.

Vanden Berge (1975): Avis Myology in Sisson and Grossman's. The Anatomy of the Domestic Animals, 5th ed .R. Getty, Vol. 2 pp. 1805-1806. W.B. Saunders Company, Philadelphia, London \& Toronto

Yom-Tov, Y. (1974): Effect of food and predation on breeding density and success, clutch size and laying date of crow (Corvus corone). -Journal of Animal Ecology, 43: 479- 497.

Yadav D N (2000): All India network project on agricultural ornithology: annual report. Gujarat agriculture university, Anand, 114

Zusi, R. L. (1967): The role of the depressor mandibulae muscle in kinesis of the avian skull. Proc. U. S. Natl. Mus, 123 (3607):128.

Zweers G. A.(1974): Structure Movement and Morphology of the feeding apparatus of the Mallard (Anas platyrhynchos L.). Neth, J. Zool., 24: 323-367. 

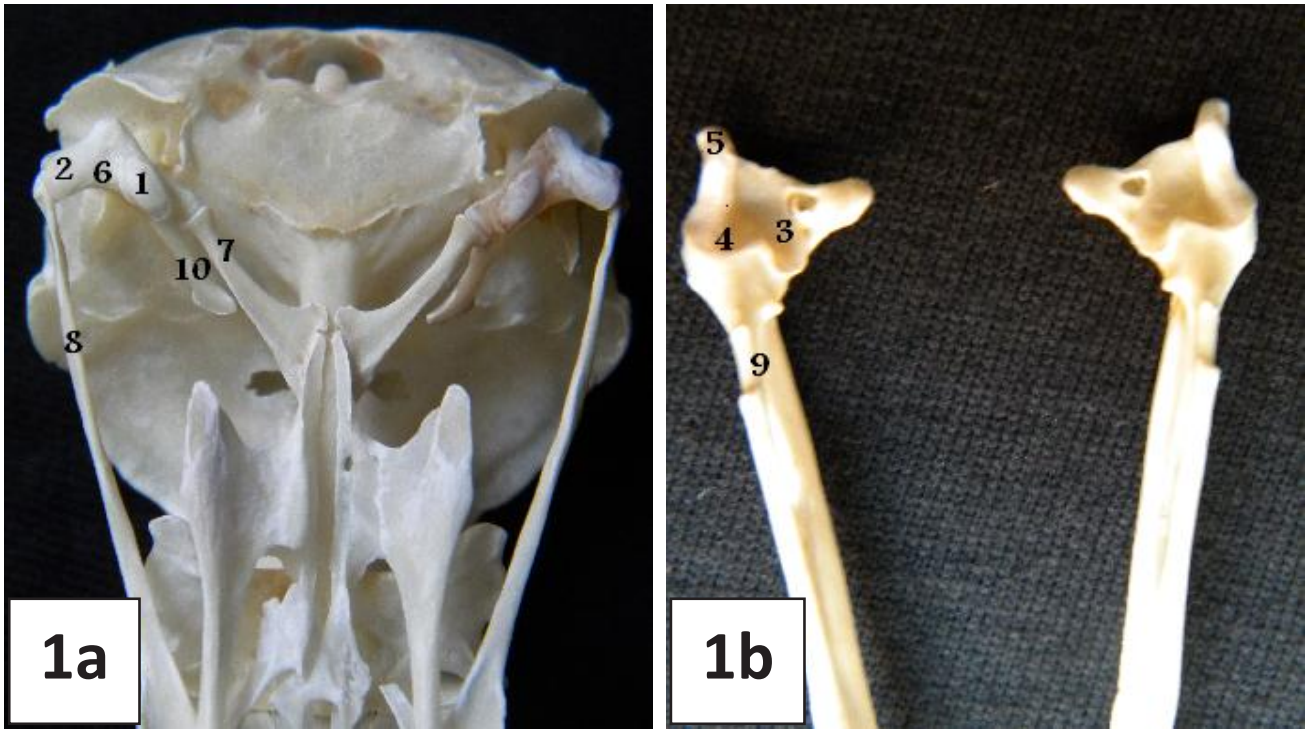

Fig (1a\&b): Photograph of the ventral surface of the skull (1a) and dorsal surface of the mandible( $1 \mathrm{~b}$ ) showing the articular surface of the quadratomandibular joint of the Hooded crow. 1 Condylus medialis, 2 Condylus lateralis, 3 Cotyla medialis, 4 Cotyla lateralis , 5 Articular process, 6 Sulcus intercondylaris, 7 Os pterygoideum, 8 Os quadratojugalis, 9 Ramus mandibulae,10 Proc. Orbitalis quadrati
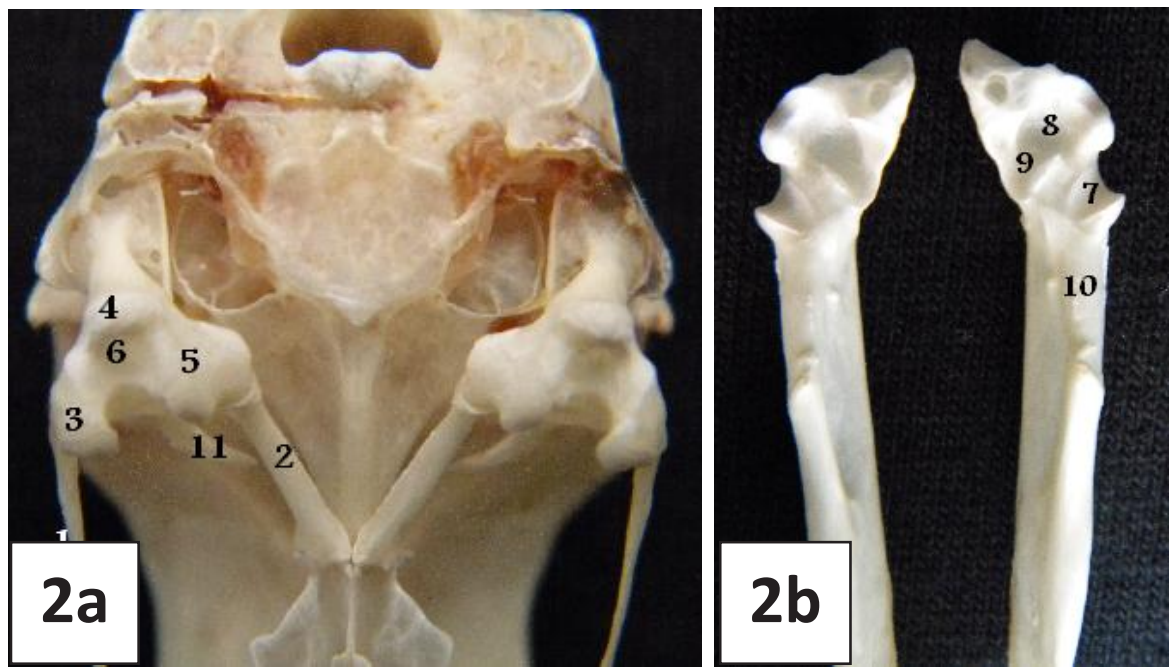

Fig (2a\&b): Photograph of the ventral surface of the skull (2a) and the ventral surface of the mandible (2b) showing the articular surface of the quadratomandibular joint of the Cattle egret.

1 Os quadratojugalis, 2 Os pterygoideum, 3 Condylus lateralis, 4 Condylus caudalis, 5 Condylus medialis, 6 Sulcus intercondylaris, 7 Cotyla lateralis, 8 Cotyla caudalis, 9 Cotyla medialis, 10 Ramus mandibulae, 11 Proc. Orbitalis quadrati. 

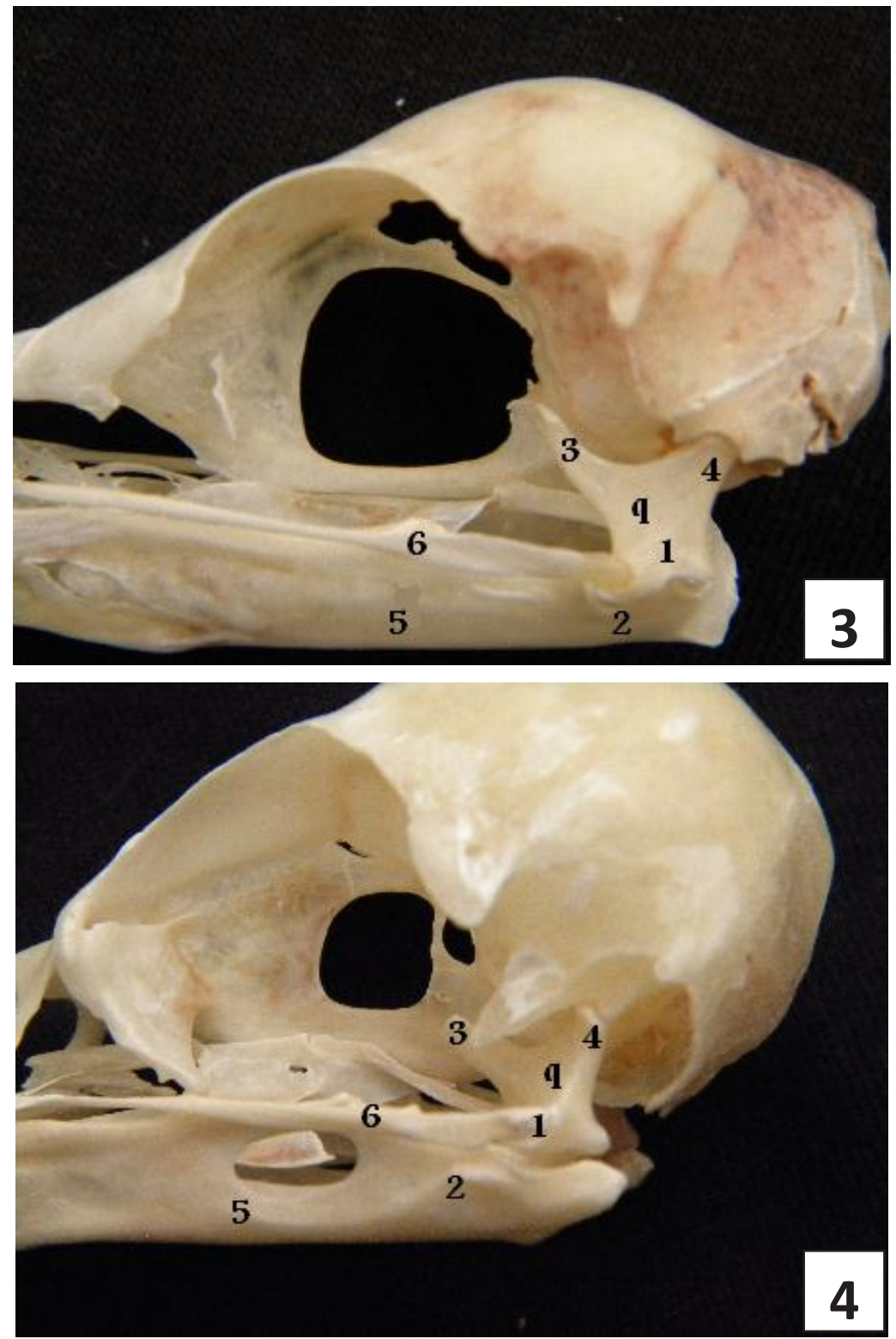

Figs (3\&4): Photograph of the lateral surface of the skulls of the Hooded crow and Cattle egret respectively; showing:

1 Proc. Mandibularis quadrati, 2 Ramus mandibulae (pars caudalis), 3 Proc. orbitalis quadrati, 4 Proc. oticus quadrati, 5 Proc. oticus quadrati, 6 Ramus mandibulae (pars intermedia), 7 Os quadratojugale,

q- Quadratum 


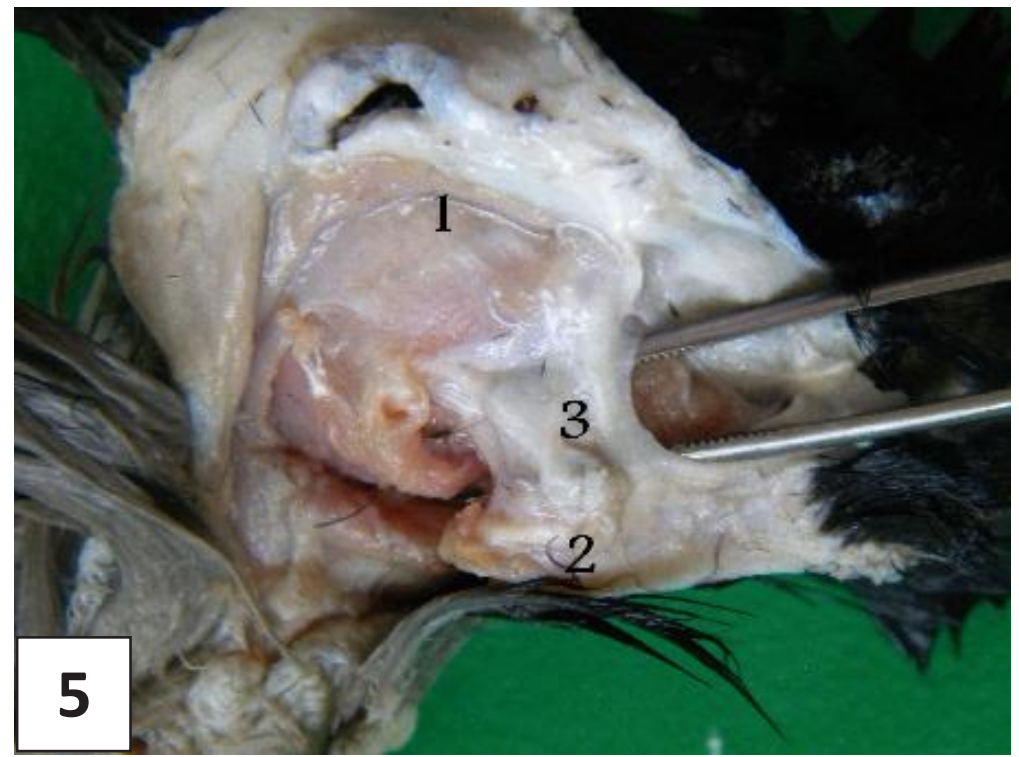

Fig (5): Photograph of the lateral surface of the quadratomandibular joint of the Hooded crow showing:

1 Os squamosum, 2 Ramus mandibulae (pars caudalis), 3 Capsula articularis

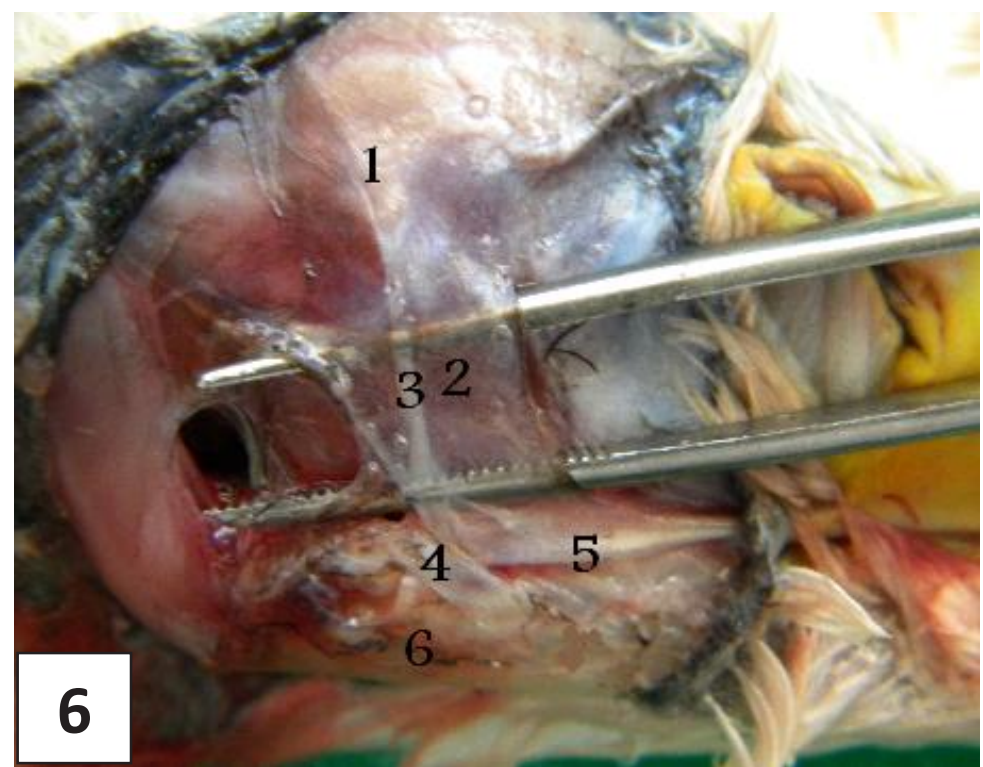

Fig (6): Photograph of the lateral surface of the quadratomandibular joint of the Cattle egret showing:

1 Proc. Zygomaticus, 2 Capsula articularis, 3 Lig. Postorbitale, 4 Lig. Jugomandibulare laterale, 5 Os quadratojugale, 6 Ramus mandibulae ( pars caudalis). 


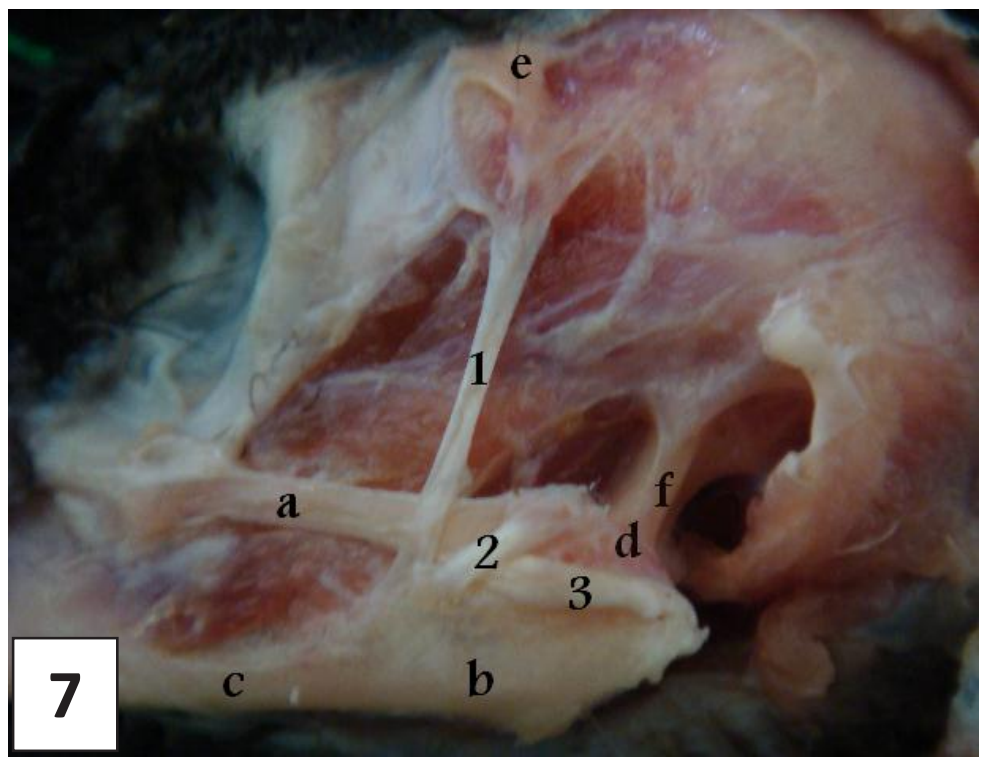

Fig (7): Photograph of the lateral surface of the quadratomandibular joint of the Hooded crow showing:

1 Lig. Postorbitale, 2 Lig. Jugomandibulare laterale, 3 Lig. Jugomandibulare mediale, a Os quadratojugalis, b Os articulare, c Ramus mandibulae, d Quadratum, e Proc. zygomaticus, f Proc. Oticus.

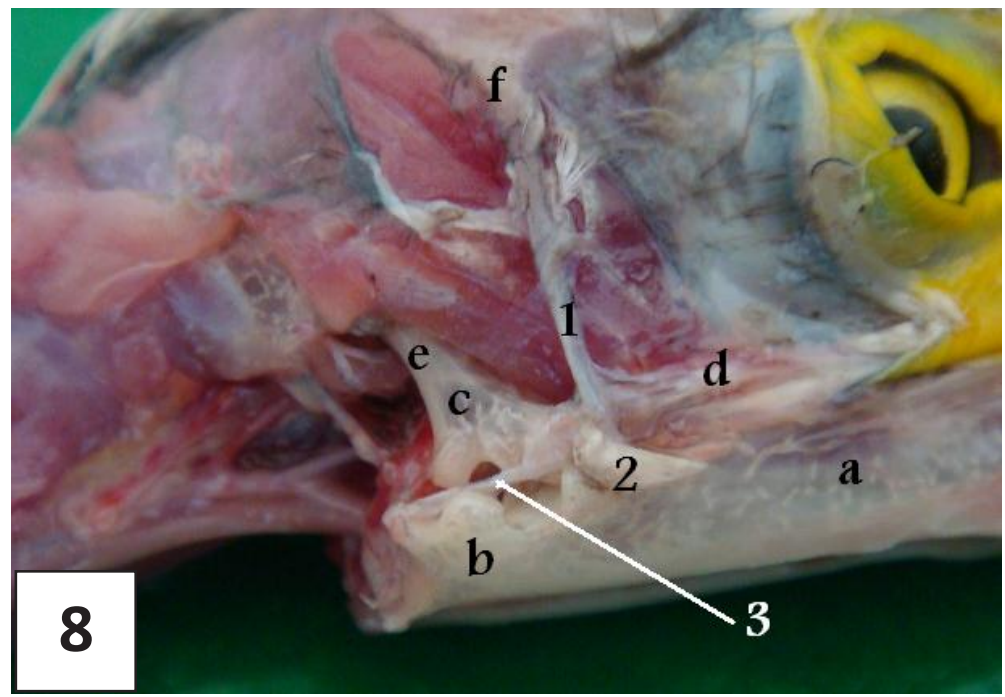

Fig (8): Photograph of the lateral surface of the quadratomandibular joint of the Cattle egret showing;

1 Lig. postorbitale, 2 Lig. jugomandibulare laterale, 3 Lig. jugomandibulare mediale, a Ramus mandibulae, b Os articulare, c Quadratum, d Os quadratojugalis, e Proc. oticus, f Proc. zygomaticus 


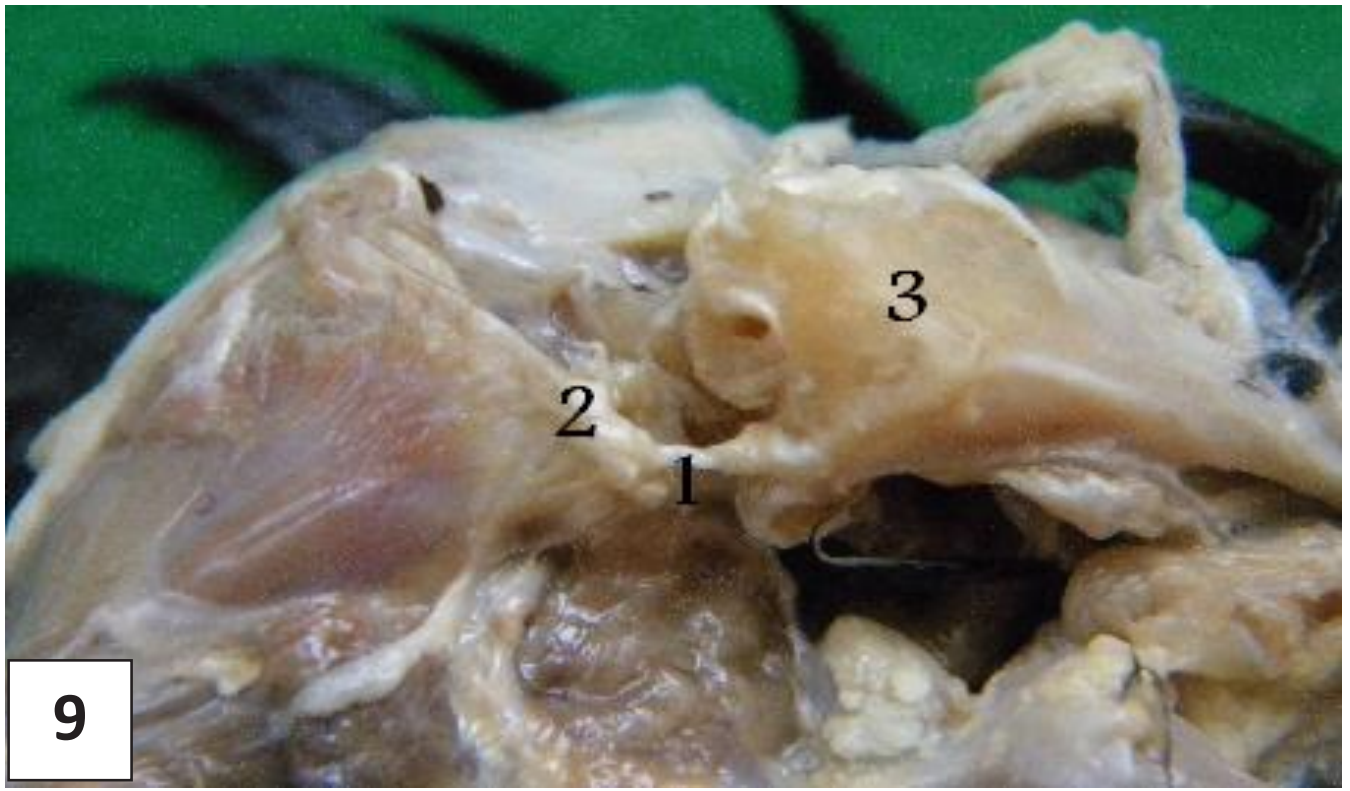

Fig (9): Photograph of the ventral surface of the quadratomandibular joint of the Hooded crow.

1 Lig. Occipitomandibulare, 2 Os exoccipitale,3 Ramus mandibulae (pars caudalis).

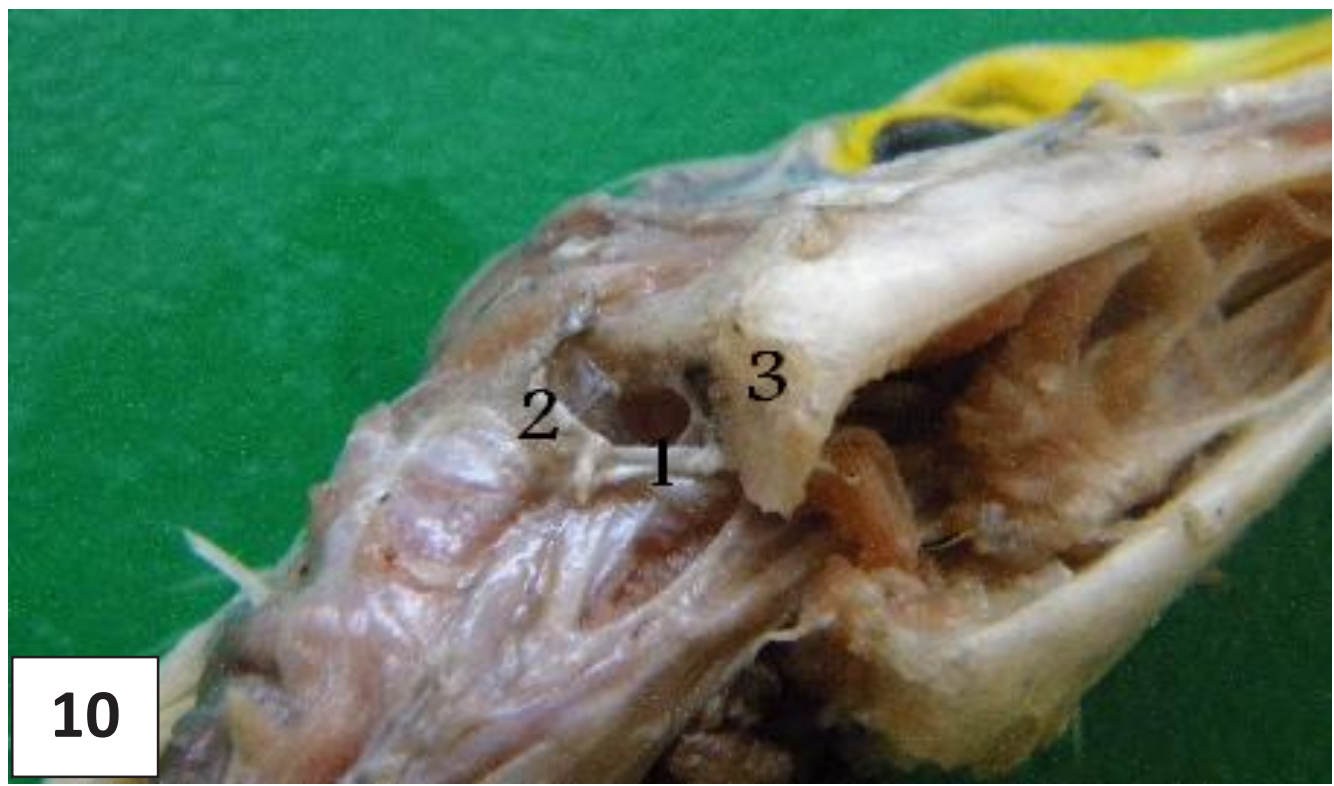

Fig (10): Photograph of the ventral surface of the quadrato-mandibular joint of the Cattle egret.

1 Lig. Occipitomandibulare, 2 Os exoccipitale, 3 Ramus mandibulae (pars caudalis).
J. Vet. Anat.
45
Vol 5 No 1, (2012) 31 - 46 


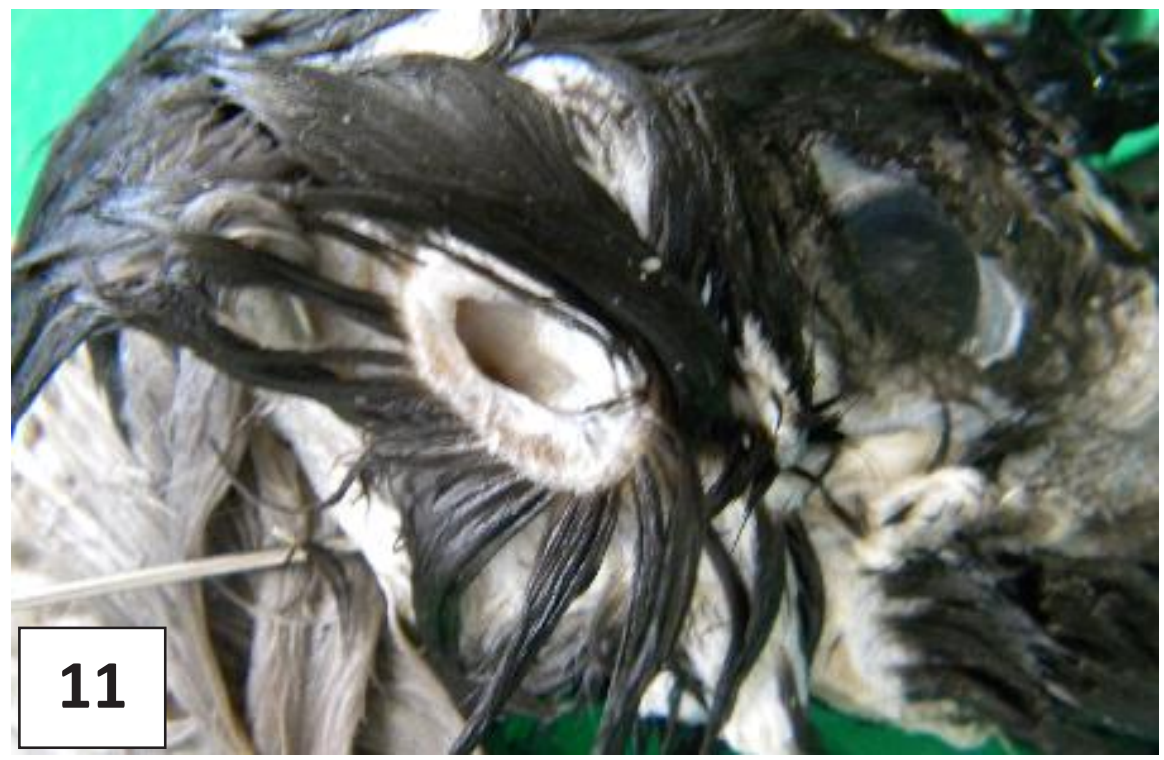

Fig (11): Photograph of the lateral surface of the head of the Hooded crow showing the site of intra-articular injection of the quadrato-mandibular joint.

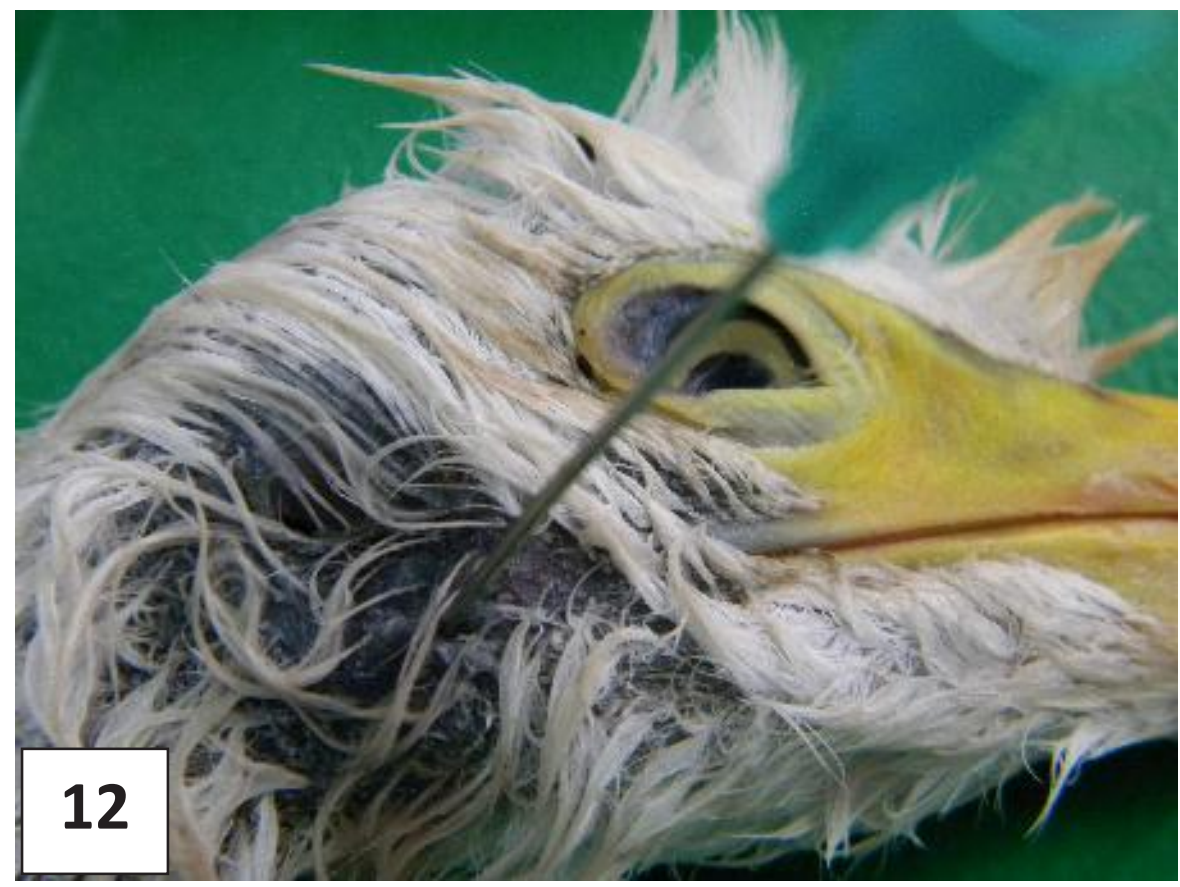

Fig (12): Photograph of the lateral surface of the head of a Cattle egret showing the site of intra-articular injection of the quadrato-mandibular joint 